Maciej Muskała

Uniwersytet im. Adama Mickiewicza w Poznaniu

Justyna Kusztal Uniwersytet Jagielloński

\title{
Kurator sqqdowy wobec nowych zadań i zmian w systemie resocjalizacii
}

\author{
Probation Officer in the Context of New Tasks \\ and Challenges in the System of Social Rehabilitation
}

\begin{abstract}
ABSTRAKT
Artykuł ma charakter prekonceptualizacyiny, stanowi bowiem przyczynek do planowanego projektu badawczego ugruntowanego w pedagogice resocjalizacyinej. Wobec ostatnich zmian w systemie zapobiegania przestępczości, tak na etapie stanowienia, jak i wykonywania prawa, autorzy widza potrzebę poddania analizie aktualnych tendencji i zmian w kontekście funkcji, ról i kompetencji kuratora sqdowego, który jest podstawowym „narzędziem" wymiaru sprawiedliwości w obszarze zapobiegania przestępczości. Tradycyine modele pracy, określane jako case work w rożnych jego odmianach, wydaja się nie do końca adekwatne do realizacji tych zadań, które zostały podczas ostatnich nowelizacji ustawowych przypisane kuratorowi sqdowemu. Ten zaś, jako „pedagogiczne ramię wymiaru sprawiedliwości", kształcony w tradycyinym modelu przygotowania zawodowego, staje przed nowymi wyzwaniami nie tylko organizacyjnymi, ale i tymi zwiqzanymi z praca w wymiarze wychowawczym. Niniejszy artykuł stanowi zarys koncepcji badawczej nakierowanej na
\end{abstract}

SLOWA KLUCZOWE probacja, kurator sqdowy, resocjalizacja, wymiar sprawiedliwości, skazany

\section{KEYWORDS}

probation, probation officer, social rehabilitation, criminal justice system, convict

SPI Vol. 21, 2018/1

ISSN 2450-5358

e-ISSN 2450-5366 DOI: 10.12775/SPI.2018.1.001

Nadestano: 31.12.2017

Zaakceptowano: 26.03.2018

Artykuły i rozprawy 
diagnozę adekwatności kompetencji i modeli pracy kuratora realizowanych w ramach nowych zadań wynikających ze zmian normatywnych w wymiarze sprawiedliwości i w systemie resocjalizacji. Artykuł zawiera obszerne uzasadnienia podjętego problemu badawczego oraz ramy koncepcii metodologicznej.

\section{ABSTRACT}

The article has a pre-conceptual character, as it contributes to the planned research project established in rehabilitation pedagogy. Due to recent changes in the crime prevention system, both at the stage of establishing and executing the law, the authors recognise the need to analyse these current trends and changes in the context of the functions, roles and competences of the probation officer, which is the basic "tool" of justice in the area of crime prevention. Traditional work models referred to as case work in its different varieties do not seem to be entirely adequate in terms of the implementation of the tasks that have been assigned to probation officers during the recent statutory amendments. This means that they, as a "pedagogical arm of the judiciary" educated in the traditional model of professional preparation, face new challenges, not only organisational, but also those related to working in an educational dimension. This article is therefore an outline of a research concept aimed at diagnosing the adequacy of competences and models of the probation officer's work for new tasks resulting from normative changes in the justice and rehabilitation system. The article contains extensive justifications for the research problem undertaken and the framework of the methodological concept.

\section{Wstęp}

Przestępczość powszechna, rozumiana jako problem społeczny, jest od wieków obecna w refleksji naukowej, tak socjologicznej, kryminologicznej, jak i prawnej czy pedagogicznej. Sama w sobie jest zjawiskiem poddającym się analizie zarówno ze względu na jej etiologię, jak i fenomenologię, a jako problem społeczny nie może być rozwiązana przez działania jednostkowe, ale wymaga szeroko 
zakrojonych działań globalnych ${ }^{1}$, opartych właśnie na wiedzy interdyscyplinarnej. Pedagogika resocjalizacyjna jako nauka rozwija się właśnie pod wpływem refleksji interdyscyplinarnej ${ }^{2}$. To na jej gruncie jest możliwe, naszym zdaniem, postawienie pytania, które stanowi główny problem badawczy niniejszego artykułu.

Jako badacze teorii i praktyki resocjalizacyjnej pozostajemy szczególnie wrażliwi na zmiany polityczne i systemowe w obszarze zapobiegania przestępczości i zdecydowanie opowiadamy się za strategiami prewencyjnymi oraz resocjalizacyjnymi w przeciwdziałaniu przestępczości i niedostosowaniu społecznemu. Wnioski z naszych obserwacji i analiz przejawów nowych tendencji światowych i lokalnych w zapobieganiu przestępczości $\mathrm{w}$ ogóle, a szczególnie w obszarze zapobiegania powtórnej przestępczości, stały się inspiracją do postawienia pytań sytuujących się niejako na pograniczu ciągłości i zmiany polskiej pedagogiki resocjalizacyjnej, na pograniczu tradycyjnej resocjalizacji, ugruntowanej w dorobku naukowym i opisach praktyki i metodyki wychowania resocjalizującego, oraz współczesnych tendencji w zapobieganiu przestępczości. Wpisujemy się więc zdecydowanie w zamysł poświęcenia tej problematyce niniejszego numeru „Studia Paedagogica Ignatiana”. Stąd też nie wahamy się postawić pytania o adekwatność tradycyjnego modelu działań resocjalizacyjnych prowadzonych w ramach resocjalizacji instytucjonalnej do nowych wyzwań, zadań i funkcji przypisanych kuratorowi sądowemu. Kurator sądowy, jako „instrument” wymiaru sprawiedliwości, jest dziś wykonawcą znakomitej większości zadań, które zleca mu reformujący się w ostatnich latach system zapobiegania przestępczości i niedostosowaniu społecznemu.

\section{Neoliberalne tendencje w polityce kryminalnej}

W powszechnym dyskursie medialnym właściwie od pierwszego dziesięciolecia XXI wieku dominuje pogląd o wzroście przestępczości. Analizy naukowe stwierdzają wzrost przestępczości będący

1 J. Sztumski, Czy możemy mówić o patologii spotecznej, w: Zjawiska patologii spotecznej. Uwarunkowania, rozmiary, profilaktyka, prognozy, red. T. Sołtysiak, Bydgoszcz 1995, s. 13, por. także I. Pospiszyl, Patologie spoteczne, Warszawa 2008, s. 11-18.

2 B. Urban, Teoria resocjalizacji w strukturze nauk spotecznych, w: Resocjalizacja, red.

B. Urban,J.M. Stanik, Warszawa 2007, s. 31 oraz rozdział 1.4 tegoż opracowania. 
wynikiem przemian społeczno-politycznych końca XX wieku, ale nie określają go jako znaczny, i co ważne, współczynniki opisujące przestępczość powszechną są zdecydowanie niższe w naszym kraju niż na zachodzie Europy ${ }^{3}$. Tymczasem relatywnie wyższy poziom przestępczości, dodatkowo „udramatyzowany” przez środki masowego przekazu, powoduje stały wzrost poczucia lęku przed przestępczością ${ }^{4}$. W związku z niezdolnością współczesnego państwa do uporania się z tym zjawiskiem, społeczeństwo traci zaufanie do organów odpowiedzialnych za rozwiązanie tego problemu. Dlatego organy te

[...] zaczęły więc postępować według nowych zasad nadających kierunek zmianom w polityce kryminalnej. Naczelnym zadaniem staje się udzielenie efektywnej ochrony społeczeństwu przed zagrożeniami jej bezpieczeństwa. Osobowość przestępcy i jego uprawnienia liczą się tylko w stopniu wymaganym podstawowymi prawami człowieka, ale najważniejsze jest „unieszkodliwić” go, pozbawić możliwości owego zagrażania [...], co odpowiada jednocześnie sprawiedliwości retrybutywnej, a więc społecznemu żądaniu odwetu karaniem ${ }^{5}$.

I choć David Garland skupia się na analizie kultury kontroli kryminalnej i sądownictwa karnego w Wielkiej Brytanii i Stanach Zjednoczonych, to można dostrzec pewne tendencje zarysowujące już swoją obecność także w innych krajach, w tym w Polsce.

Punitywność, definiowana niejednoznacznie przez Krzysztofa Krajewskiego ${ }^{6}$, Mirosławę Melezini ${ }^{7}$ czy Waldemara Jarocha ${ }^{8}$, jest

3 K. Krajewski, Czy w Europie istniejq dwie odrębne strefy „klimatu penalnego”, w: Pañstwo prawa i prawo karne. Ksiega jubileuszowa Profesora Andrzeja Zolla, t. 2, red. W. Wróbel, P. Kardas, T. Sroka, Warszawa 2012, s. 1413-1430.

4 Co ciekawe, poziom lęku w danym społeczeństwie niejednokrotnie jest niezależny od aktualnego poziomu przestępczości. Przykładem może być Polska, gdzie poczucie lęku jest znacznie wyższe niż w krajach o większej przestępczości. Na ten temat patrz m.in.: A. Siemaszko, B. Gruszczyńska, M. Marczewski, Atlas przestępczości w Polsce. 3, Warszawa 2003.

5 K. Poklewski-Koziełt, rec.: David Garland, The Culture of Control: Crime and Social Order in Contemporary Society, Chicago 2001, „Państwo i Prawo” 2002, nr 12, s. 85.

6 K. Krajewski, Czy w Europie istnieja dwie odrębne strefy „klimatu penalnego”?, dz. cyt.

7 M. Melezini, Punitywnośc wymiaru sprawiedliwości karnej Polsce w XX wieku, Białystok 2003.

8 W. Jaroch, Polityka karna - strategia punitywna czy liberalna, „Studia Prawnoustrojowe" 2012, nr 15, s. 49-61. 
w naszym kraju widoczna na etapie stanowienia oraz wykonywania prawa. Przeprowadzona przez Jarocha obszerna analiza pozwala wyprowadzić wniosek, że mimo nie tak znacznego wzrostu przestępczości powszechnej w naszym kraju, nastąpiło w ciągu ostatnich lat praktycznie niczym nieuzasadnione zaostrzenie granic odpowiedzialności karnej za niektóre przestępstwa oraz "usztywnienie” i zbiurokratyzowanie reakcji prawa karnego na etapie stosowania prawa'. Obecnie dominujący w krajach o wyższej kulturze prawnej neoklasyczny paradygmat w kryminologii i polityce kryminalnej przejawia się powrotem do idei klasycznego prawa karnego, według którego sprawca czynu karalnego jest odpowiedzialny za swoje postępowanie, a reakcje prawa karnego są proporcjonalne do ciężaru czynu i stopnia zawinienia ${ }^{10}$. Reakcje prawne nastawione są retrybutywnie, nie tyle na samego sprawcę, ale na ochronę społeczeństwa, czyli na prewencję ogólną. Resocjalizacja staje się nie celem, ale środkiem do celu, i to jednym $z$ wielu (obok miedzy innymi odstraszania czy uniemożliwiania), niekoniecznym i zdecydowanie zbyt kosztownym, aby można było ją stosować wobec wszystkich ${ }^{11}$.

Konsekwencją przemian w myśleniu o przestępcy, a także o karze i sposobach jej wykonywania, jaka dokonała się na przestrzeni ostatnich dziesięcioleci, była konieczność wypracowania nowych mechanizmów przeciwdziałania przestępczości i recydywie, w których probacja znalazła swoje poczesne miejsce.

\section{Probacja w kontekście przemian legislacyjnych i systemowych}

Probację można definiować na wiele sposobów, przy czym samo „pojęcie probacji jest jednym z najbardziej nieostrych w literaturze z obszaru prawa, polityki kryminalnej czy pedagogiki resocjalizacyjnej. Przyjęcie jednej, choćby najbardziej szerokiej definicji, wydaje się ryzykowne” ${ }^{12}$. „Środki probacyjne jako reakcje na czyny karalne

9 Por. tamże.

10 J. Błachut, A. Gaberle, K. Krajewski, Kryminologia, Gdańsk 1999, s. 55.

11 Por. B. Stańdo-Kawecka, Ruch What works i „nowa resocjalizacja” - nowa perspektywa w polityce karnej?, w: Węztowe problemy prawa karnego, kryminologii i polityki kryminalnej, red. V. Konarska-Wrzosek, J. Lachowski, J. Wójcikiewicz, Warszawa 2010, s. 891-907.

12 J. Kusztal, A. Siuda, Probacja w sprawach nieletnich - doświadczenia szkockie, w: Profilaktyka i probacja w środowisku lokalnym, red. B. Urban, 
ogólnie zakładają: pozostawanie na wolności w określonym czasie i spełnienie $\mathrm{w}$ tym czasie określonych przez sąd obowiązków pod nadzorem wskazanej osoby (często, choć nie zawsze) kuratora ${ }^{13}$.

Instytucja kurateli sądowej w literaturze, ale też w potocznym rozumieniu, utożsamiana jest $\mathrm{z}$ probacją. Ta zaś opisuje pozostawanie sprawcy przestępstwa na wolności pod dozorem innej osoby - właśnie kuratora - na określony czas. Idea probacji była wtórna wobec praktyki i wyrosła w krajach anglosaskich, przy czym historycznie rozwinęła się ona w dwóch opisanych w literaturze modelach: anglosaskim (angielsko-amerykańskim) i francusko-belgijskim ${ }^{14}$.

Modele te, obok istotnej różnicy związanej ze specyfiką systemu common law, gdzie praktyka wyprzedza regulacje prawne i prawa kontynentalnego, gdzie instytucje (prawne) mają rację bytu dopiero po wejściu w życie stosownych norm prawnych, mają pewne wspólne cechy. Modele te opierają się głównie na pracy kuratora zawodowego o wysokiej specjalizacji, działającego w pionie pracowników socjalnych. Kuratorzy są instytucjonalnie uniezależnieni od sądownictwa, choć ich praca skupia się między innymi na świadczeniu pomocy sądowej. W pracy kuratorów z samym kuratelnym, jak i jego rodziną, środowiskiem szkolnym czy zawodowym, dominują elementy wychowawcze i terapeutyczne ${ }^{15}$.

W polskim systemie prawa karnego wyróżnia się następujące środki probacyjne: warunkowe umorzenie postępowania karnego, warunkowe zawieszenie wykonania kary pozbawienia wolności i warunkowe zwolnienie $\mathrm{z}$ odbycia reszty kary pozbawienia wolności (art. 66-84 kk $)^{16}$. Natomiast obowiązki probacyjne, które może nałożyć na skazanego sąd, określa art. 72 § 1 i 2 kk. Należą do nich między innymi: informowanie sądu lub kuratora o przebiegu okresu

M. Konopczyński, Kraków 2013, s. 430, por także: D. Wójcik, Probacja rozwiazania prawne w niektórych krajach europejskich, „Archiwum Kryminologii" 1999-2000, t. 25, s. 29-79, Alternatywy pozbawienia wolności w polskiej polityce karnej, red. J. Jakubowska-Hara, J. Skupiński, Warszawa 2009; A. Bałandynowicz, Probacja: wychowanie do wolności, Grodzisk Mazowiecki 1996.

13 J. Kusztal, A. Siuda, Probacja w sprawach nieletnich - doświadczenia szkockie, dz. cyt., s. 430.

14 J. Kusztal, Prawne podstawy kurateli sądowej, w: Wspótczesna kuratela sądowa, red. B. Zinkiewicz, Mysłowice 2006, s. 11-20.

15 Tamże.

16 Ustawa z dnia 6 czerwca 1997 r. - Kodeks karny, Dz.U. 1997 nr 88 poz. 553 ze zmianami. 
próby, przeproszenie pokrzywdzonego, wykonywanie ciążącego na skazanym obowiązku łożenia na utrzymanie innej osoby, wykonywanie pracy zarobkowej, podjęcie nauki lub przygotowania się do zawodu, powstrzymanie się od nadużywania alkoholu lub używania innych środków odurzających, poddanie się leczeniu, w szczególności odwykowemu lub rehabilitacyjnemu, albo oddziaływaniom terapeutycznym lub uczestnictwu w programach korekcyjno-edukacyjnych, powstrzymanie się od przebywania w określonych środowiskach lub miejscach, powstrzymanie się od kontaktowania się z pokrzywdzonym lub innymi osobami w określony sposób, opuszczenie lokalu zajmowanego wspólnie z pokrzywdzonym ${ }^{17}$. Obowiązki te mają zdecydowanie charakter wychowawczy i faktycznie są związane z ograniczeniem wolności przez osobę je podejmującą. Podczas stosowania środków probacyjnych można je połączyć z dozorem kuratora sądowego, który polega na stawianiu się na wezwania sądu lub kuratora sądowego, udzielaniu wyjaśnień co do przebiegu dozoru, informowaniu kuratora o zmianie miejsca zatrudnienia, zamieszkania i pobytu i umożliwianiu wejścia do mieszkania (art. 73-74 kk) ${ }^{18}$. Równocześnie - mimo utrzymujących się w społeczeństwie tendencji punitywnych - polski ustawodawca (niestety niekonsekwentnie) czyni kroki w kierunku „rozluźnienia” systemu wymiaru sprawiedliwości opartego na bezwzględnej karze pozbawienia wolności, wprowadzając środki realizowane nie w izolacji, ale $\mathrm{w}$ środowisku otwartym. Już w 2007 roku wprowadzono dozór elektroniczny jako alternatywę dla pozbawienia wolności w zakładzie karnym ${ }^{19}$, a od roku 2015 karę ograniczenia wolności realizowaną w systemie dozoru elektronicznego $^{20}$. Podczas gdy dozór elektroniczny realizowany jest z powodzeniem i systematycznie wzrasta liczba osób nim objętych ${ }^{21}$, to kara

Tamże, art. $72 \S 1$ i 2.

18 Tamże, art. 74.

19 Ustawa z dnia 7 września 2007 r. o wykonywaniu kary pozbawienia wolności poza zakładem karnym w systemie dozoru elektronicznego, Dz.U. 2007 nr 191 poz. 1366, uchylona Ustawą z dnia 20 lutego 2015 r. o zmianie ustawy - Kodeks karny oraz niektórych innych ustaw Dz.U. 2015 poz. 396.

20 Ustawa z dnia 20 lutego 2015 r. o zmianie ustawy - Kodeks karny oraz niektórych innych ustaw Dz.U. 2015 poz. 396.

21 Dane Biura Dozoru Elektronicznego Służby Więziennej, <http://www. sw.gov.pl/jednostka/biuro-dozoru-elektronicznego> [dostęp: 2.01.2018]. 
ograniczenia wolności w systemie dozoru elektronicznego orzekana na etapie postępowania sądowego, jak pokazują statystyki, nie stała się realnym środkiem karnym i alternatywą dla krótkoterminowej kary pozbawienia wolności. „Dlatego też niezbędne jest podjęcie dalszych reform polskiego ustawodawstwa karnego w duchu Rekomendacji CM/ Rec(2014)4 i innych międzynarodowych standardów określających katalog, zasady i tryb stosowania środków oddziaływania na sprawców czynów zabronionych w systemie dozoru elektronicznego"22.

Podsumowanie wszystkich orzeczeń związanych z szeroko rozumianą probacją (przede wszystkim sprawowanie dozorów w przypadku warunkowego zwolnienia, zawieszenia bądź umorzenia kary, wykonywanie kary ograniczenia wolności oraz pracy społecznie użytecznej orzeczonej na podstawie art. $45 \mathrm{kkw}$, jak i wykonywanie dozoru elektronicznego) wykazuje, że ponad 1\% ludności kraju objętych jest jakimś środkiem probacyjnym, co plasuje nasz kraj w niechlubnej czołówce europejskiej.

Warto jednak zaznaczyć, że

orzekanie wielu środków o charakterze probacyjnym bez rzetelnej diagnozy musi prowadzić do licznych przypadków niepomyślnego zakończenia próby i znacznego odsetka zarządzeń wykonania kar pozbawienia wolności warunkowo zawieszonych, co w konsekwencji skutkuje umieszczeniem skazanego w zakładzie karnym. Przy spadającej liczbie osób tymczasowo aresztowanych i w miarę stałym poziomie skazań na karę pozbawienia wolności, to właśnie szafowanie warunkowym zawieszeniem bez możliwości jej efektywnego odbycia, co skutkuje zarządzeniem wykonania kary, jest główną przyczyną utrzymywania się tak wysokiego wskaźnika prizonizacji ${ }^{23}$.

22 R. Pelewicz, Czynniki normatywne utrudniajace efektywne stosowanie instrumentów reakcji karnej w systemie dozoru elektronicznego na tle ostatnich nowelizacji, „Przegląd Więziennictwa Polskiego” 2017, nr 95, s. 140.

23 M. Muskała, ,Odstapienie od przestępczości” w teorii i praktyce resocjalizacyjnej, Poznań 2016, s. 35-36. Orzekanie tak wielu środków o charakterze probacyjnym pociąga za sobą wiele negatywnych konsekwencji, które najczęściej określa się mianem net-widening. Pojęcie to jest odnoszone do wzrostu liczby osób mających kontakt $\mathrm{z}$ systemem wymiaru sprawiedliwości i definiowane jako niezamierzony wynik zastosowania nowych praktyk. $Z$ cytowanych przez Thomasa G. Blomberga i współpracowników badań wynika, że net-widening może osiągać od $10 \%$ aż do $50 \%$. Sankcje alternatywne, które w swym zamyśle miały m.in. wpłynąć na zmniejszenie wielkości populacji więziennej, poprzez stosowanie ich wobec sprawców drobnych przestępstw, którzy przy ich braku w wachlarzu środków i kar pozostających w dyspozycji sądów otrzymaliby krótkie, kilkumiesięczne, kary pozbawienia wolności, niestety nie spełniły tych oczekiwań. Drobni przestępcy jak trafiali, tak dalej 
Orzekanie tak wielu środków o charakterze probacyjnym przy tak niewielkich zasobach, zwłaszcza kadrowych (liczba sądowych kuratorów zawodowych niewiele przekracza $5000^{24}$, z czego dla dorosłych to 3126,25 etatów, wspiera ich 15809 kuratorów społecznych dla dorosłych ${ }^{25}$ ), musi prowadzić do licznych przypadków niepomyślnego zakończenia próby i znacznego odsetka zarządzeń wykonania kar pozbawienia wolności warunkowo zawieszonych, co skutkuje umieszczeniem skazanego w zakładzie karnym.

Obrazują to choćby dane dotyczące powrotności do przestępstwa osób dorosłych z wyrokiem pierwszej instancji pozbawienia wolności $\mathrm{w}$ zawieszeniu z dozorem kuratora sądowego w ciągu pięciu lat od prawomocnego skazania.

trafiają do zakładów karnych na kary krótkoterminowe, natomiast sankcjom pośrednim poddawane są osoby, które w innych okolicznościach pozostawałyby poza oddziaływaniem organów wymiaru sprawiedliwości. Jak zauważa Paweł Moczydłowski w swojej pracy poświęconej monitoringowi elektronicznemu, zastosowanie tego środka może zwiększać zakres kontroli społecznej, a ponadto „problem leży nie tylko w tym, że zostaje wprowadzony nowy środek karny, który może prowadzić do powiększenia populacji osób karanych, ale i w tym, że sama kara może okazać się surowsza”. P. Moczydłowski, Przestępca na uwięzi. Elektroniczny monitoring sprawców przestępstw, (Zeszyty Naukowe „Ius et Lex”, z. 2), Warszawa 2006, s. 42. Zwłaszcza ta ostatnia uwaga pokazuje, że net-widening może nastąpić na każdym etapie kontaktu $\mathrm{z}$ wymiarem sprawiedliwości. Koresponduje $\mathrm{z}$ tym znacznie rozszerzona definicja omawianego zjawiska zaproponowana przez Jamesa Austina i Barry’ego Krisberga, włączająca w jego obszar także szersze (wider), mocniejsze (stronger) i różne (different) sieci. Oznacza to wzrost czasu trwania lub nasilenie interwencji karnych, a także kreowanie nowych podmiotów (instytucji, agend), którym przekazuje się nadzór i wykonywanie kar. Należy podkreślić, że analizując literaturę dotyczącą zagadnienia net-widening, można spotkać argumenty pokazujące przynajmniej potencjalnie pozytywne konsekwencje tego zjawiska. Sugeruje się, że owo rozszerzenie sieci może się przyczynić do zwrócenia uwagi społeczności, środowiska lokalnego na dotychczas niedostrzegane i nierozwiązane problemy społeczne, takie jak choćby przemoc w rodzinie czy nadużywanie substancji psychoaktywnych. W tym drugim przypadku net-widening ma być pomocne $\mathrm{w}$ dotarciu przez służbę zdrowia i instytucje odpowiedzialne za profilaktykę i leczenie do osób używających środków odurzających. Por. J Austin, B. Krisberg, NCCD Research Review: Wider, Stronger, and Different Nets: the Dialectics of Criminal Justice Reform, „Journal of Research in Crime and Delinquency” 1981, t. 18, nr 1, s. 165-196.

${ }^{24} 5037$ w 2014 roku, 5031 w 2015 roku - Maty Rocznik Statystyczny Polski. 2016, Warszawa 2016, s. 83.

25 Sprawozdanie MS-S40 na dzień 30.06.2014 r. 
Tabela nr 1. Powrotność do przestępstwa

\begin{tabular}{|c|c|c|c|c|}
\hline & 2009 & 2010 & 2011 & 2012 \\
\hline Prawomocnie skazani & 60351 & 58111 & 55938 & 52567 \\
\hline \multicolumn{5}{|c|}{ Osoby, które powróciły do przestępstwa: } \\
\hline - w ciqgu pięciu lat & 19142 & 19418 & 19525 & 17886 \\
\hline - w pierwszym roku & 10080 & 10615 & 10907 & 9736 \\
\hline - w drugim roku & 4776 & 4811 & 4736 & 4318 \\
\hline - w trzecim roku & 2792 & 2708 & 2651 & 2485 \\
\hline - w czwartym roku & 1296 & 1110 & 1114 & 1176 \\
\hline - w piqtym roku & 198 & 174 & 117 & 171 \\
\hline
\end{tabular}

Źródło: Na podstawie opracowania Powrotność do przestępstwa w latach 2009-2016, Ministerstwo Sprawiedliwości, Departament Strategii i Funduszy Europejskich, Wydział Statystycznej Informacii Zarzqddczej, Warszawa 2017.

Choć liczba osób prawomocnie skazanych na karę pozbawienia wolności w zawieszeniu $\mathrm{z}$ dozorem kuratora sądowego w analizowanym okresie poważnie spadła, to poziom powrotności nieznacznie wzrósł (wynosił on odpowiednio w latach: 2009 - 31,7\%; 2010 33,4\%; 2011 - 34,9\%; $2012-34,0 \%)^{26}$. Warto podkreślić w kontekście podjętej problematyki, że ponad 50\% przypadków powrotu na drogę przestępstwa przypada na pierwszy rok próby.

Aktualnie najbardziej istotnym aspektem działalności probacyjnej staje się proces reintegracji skazanych ze środowiskiem lokalnym. I choć atmosfera wokół probacji nie zawsze była przychylna, jej aktualne znaczenie wynika z następujących przesłanek:

1) nie wszystkie przestępstwa są na tyle poważne, a ich sprawcy na tyle zdemoralizowani, by w ramach dbałości o bezpieczeństwo publiczne

26 Zdajemy sobie sprawę, że analizy które prezentujemy nie dotyczą danych za 2017 rok ani nawet za rok poprzedzający. Na tym etapie prac projektowych nie mamy możliwości wnioskowania o udostępnienie statystyk Ministerstwa Sprawiedliwości co do interesującego nas obszaru aktywności wymiaru sprawiedliwości, tym samym korzystamy $\mathrm{z}$ danych powszechnie dostępnych w sieci. 
stosować bezwzględną karę pozbawienia wolności, 2) niemal wszystkie osoby po odbyciu kary więzienia wracają do społeczeństwa, a współcześnie nikt już nie wątpi w negatywne konsekwencje izolacji penitencjarnej, przejawiające się również ogromnymi problemami w procesie readaptacji społecznej, rozumianej jako ponowne podejmowanie prospołecznych ról, 3) kontrola sprawców przestępstw jest dużo efektywniejsza niż pozostawienie ich samym sobie ${ }^{27}$.

\section{Zadania i metody pracy kuratora}

Kuratorzy zawodowi i społeczni jako funkcjonariusze publiczni są objęci szczególną ochroną w realizacji swoich zadań ${ }^{28}$. Stanowiąc organy postępowania wykonawczego, jak zaznaczyliśmy wyżej, realizują wiele zadań w tym obszarze, ale oprócz tego są odpowiedzialni za realizację zadań z obszaru prawa rodzinnego i opiekuńczego, ustawy o ustroju sądów powszechnych, ustawy o postepowaniu w sprawach nieletnich czy ustawy o wychowaniu w trzeźwości i przeciwdziałaniu alkoholizmowi ${ }^{29}$. Wracając jednak na grunt probacji, należy podkreślić, że „kuratorzy realizują zadania głównie dla sądu, a traktowanie kurateli jako probacji jest nie tylko mylące, ale z powodu małej skuteczności realizowanych przez nią zadań dla walki z przestępczością, wręcz utrudnia adaptację idei probacji w polskim społeczeństwie" ${ }^{30}$. Trudno jest na łamach niniejszego krótkiego opracowania wskazać na podobieństwa i różnice znaczenia kurateli i probacji, zdecydowanie jednak widzimy potrzebę akcentowania odmienności tych pojęć. W literaturze przedmiotu, szczególnie $z$ obszaru pedagogiki

27 A. Barczykowska, S. Dzierzyńska-Breś, M. Muskała, Systemy oddziatywań resocjalizacyjnych Anglii i Stanów Zjednoczonych, Poznań 2015, s. 175.

28 M. Niewiadomska-Krawczyk, Kurator sqdowy jako funkcjonariusz publiczny - rozważania na tle art. 115 par. 13 pkt 3 kk, „Przegląd Więziennictwa Polskiego" 2016, nr 93, s. 26.

29 Ustawa z dnia 25 lutego 1964 r. - Kodeks rodzinny i opiekuńczy, Dz.U. 1964 nr 9 poz. 59, ze zmianami; Ustawa z dnia 27 lipca 2001 r. Prawo o ustroju sądów powszechnych,Dz.U. 2001 nr 98 poz. 1070 ze zmianami; Ustawa z dnia 26 października 1982 r. o postępowaniu w sprawach nieletnich, Dz.U. 1982 nr 35 poz. 228 ze zmianami; Ustawa z dnia 26 października 1982 r. o wychowaniu w trzeźwości i przeciwdziałaniu alkoholizmowi, Dz.U. $1982 \mathrm{nr} 35$ poz. 230 ze zmianami, tj. Dz.U. 2016 r. poz. 487.

30 R. Pelewicz, Czynniki normatywne utrudniajace efektywne stosowanie instrumentów reakcji karnej w systemie dozoru elektronicznego na tle ostatnich nowelizacji, dz. cyt., s. 135 . 
resocjalizacyjnej, niejednokrotnie pojęcia te używane są zamiennie, co nie pozwala czasem zachować klarowności wywodu i generuje kolejne błędy merytoryczne. Jak stwierdza z kolei Paweł Moczydłowski, kurator występuje głównie jako pomocnik sędziego, co wymaga szczególnego podkreślenia, „gdyż bez zrozumienia tego fenomenu nie do pojęcia jest olbrzymia ilość biurokratycznej pracy, jaką dla obsługi sądów wykonują kuratorzy - bez żadnych widocznych efektów, z wyjątkiem pełnej realizacji potrzeby dokumentacyjnej sądu" ${ }^{31}$. W efekcie realizacja resocjalizacyjnych i wychowawczych zadań kuratora „możliwa jest tylko na zasadzie biurokratycznego załatwienia sprawy i nie trzeba pogłębionych badań, by zdać sobie sprawę z niemożności ich rzetelnego wykonania"32. Z kolei według Roberta Pelewicza właśnie „takie rozwarstwienie i dublowanie podmiotowe czynności w zakresie nadzoru nad wykonywaniem kary pozbawienia wolności w systemie dozoru elektronicznego (środków karnych i środków zabezpieczających wykonywanych $\mathrm{w}$ tym systemie) pozbawione jest racjonalnego uzasadnienia aksjologicznego i organizacyjnego"33.

W XX wieku było powszechnie przyjęte, że „relacyjna podstawa” dozoru była kluczem do jego skuteczności. Istotne było skupienie się na osobistej relacji między kuratorami a indywidualnymi przestępcami oraz wiara w osobisty wpływ pracownika sądu na podopiecznego. Case work pozostawał głównym instrumentem kuratora. Jednak od kilku lat wiele opracowań zaczęło przesuwać zarówno myślenie, jak i praktykę w innym kierunku, określanym jako case management, czyli upraszczając: „zarządzanie indywidualnym przypadkiem” zastąpiło „pracę z indywidualnym przypadkiem”.

Choć koncepcja resocjalizacyjna przetrwała, pomimo wszelkich przeciwności dostosowując się do trzech dominujących dyskursów nowoczesnego systemu karnego, to napięcia pomiędzy ustaleniami evidence-based practice ${ }^{34}$ a tymi zdobywającymi na gruncie kurateli są-

31 P. Moczydłowski, Przestępca na uwięzi. Elektroniczny monitoring sprawców przestepstw, „Zeszyty Naukowe Ius et Lex” 2006, nr 2, s. 103.

32 Tamże, s. 134.

33 R. Pelewicz, Czynniki normatywne utrudniajace efektywne stosowanie instrumentów reakcji karnej w systemie dozoru elektronicznego na tle ostatnich nowelizacji, s. 135.

34 Zob. M. Muskała, „Odstapienie od przestępczości” w teorii i praktyce resocjalizacyjnej, dz. cyt., s. 89 i nast. 
dowej coraz większe znaczenie menedżeryzmem są poważne i realne. Te trzy dyskursy to odpowiednio: utylitaryzm, menedżeryzm i podejście punitywne. Narracje utylitarne podkreślają ogólne korzyści z redukcji przestępczości, które są rezultatem skutecznej resocjalizacji, punitywizm dąży do zaspokojenia społecznego pragnienia wymierzania surowych kar, menedżeryzm zaś poszukuje opłacalności i przewidywalnej kontroli ryzyka.

Probacja na przestrzeni ostatnich lat jest coraz bardziej opisywana w dyskursie „kierowania”. Rozpoczą się proces, w którym znane pojęcie "pracy z jednostką" (case work) zostało zastąpione przez „kierowanie jednostką”, czego ewidentnym przykładem są poziomy ryzyka powrotności do przestępstwa, których szacowanie jest zadaniem kuratora ${ }^{35}$.

W kontekście opisanych wyżej wielu obszarów aktywności kuratora i coraz bardziej specjalistycznych zadań, należy postawić pytanie o możliwość dobrego przygotowania kuratora do pracy, ale jeszcze bardziej „palące” jest pytanie o kierunek tego przygotowania, gdyż zmiana $\mathrm{z}$ modelu case work na case menagement stała się faktem. „Pedagogiczne ramię wymiaru sprawiedliwości” wydaje się być zastępowane przez „organizacyjne” ramię - im bardziej szybkie i sprawne, tym lepiej...

Literatura pedagogiczna wciąż jednak ,nawołuje” do refleksji nad słusznością powrotu do tradycyjnych metod pracy kuratorskiej:

Kurator respektujący w pracy z podopiecznymi zasady case worku może skutecznie rozwiązać dostrzegalne konflikty między wymogami kontroli społecznej a oddziaływaniami polegającymi na wychowaniu, może zrównoważyć prawo do podmiotowości i autonomii osoby dozorowanej z nadaną mu przez sąd władzą i autorytetem formalnym, może wreszcie połączyć opiekuńczą kontrolę wynikającą z orzeczonego środka probacyjnego z oddziaływaniami resocjalizacyjnymi stymulującymi konstruktywne funkcjonowanie podopiecznego $\mathrm{w}$ środowisku społecznym ${ }^{36}$.

Ustawa z dnia 6 czerwca 1997 r. - Kodeks karny wykonawczy, Dz.U. 1997 nr 90 poz. 557 ze zmianami, rozdział XI: Prawa i obowiązki kuratora sądowego, wykonywanie dozoru, warunkowego umorzenia postępowania i warunkowego zawieszenia wykonania kary, art. 169-176.

36 A. Węgliński, Autoprezentacja bezpośrednich oddziatywań wychowawczych spotecznych kuratorów sq̨owych „Lubelski Rocznik Pedagogiczny” 2016, t. 35, z. 2 , s. 57 . 
Marek Heine i Violetta Będkowska-Heine rozważali problem adekwatności aktualnego systemu kształcenia pedagogów specjalnych (w tym pedagogów resocjalizacji) do stojących przed nimi zadań wychowawczych i edukacyjnych ${ }^{37}$. Kompetencyjny model kształcenia, który dominuje obecnie w edukacji, zakłada, że efektem kształcenia i przygotowania zawodowego jest właśnie pakiet kompetencji osobowych, poznawczych, behawioralnie obserwowanych postaw do pracy w określonym obszarze aktywności ${ }^{38}$. Kuratela (zarówno rodzinna, jak i kuratela dla dorosłych) może być tylko jednym z obszarów aktywności zawodowej pedagoga resocjalizacji, ale kompetencje do pracy z osobami niedostosowanymi społecznie są niezbędne szczególnie w tym właśnie obszarze. Można przyjąć, że zdobywanie kompetencji odbywa się w procesie „terminowania do zawodu”, na przykład podczas staży czy aplikacji, aczkolwiek otwarte pozostaje pytanie o dobro podopiecznych czy dozorowanych ${ }^{39}$.

Tymczasem kierowanie/zarządzanie jednostką coraz bardziej widoczne jest w praktyce i „dyrektywach” pracy kuratora sądowego. Przykładem może być aktualny „podręcznik” metodyki pracy kuratora sądowego. W ciagu ostatnich dziesięciu lat ukazały się cztery wydania tej, z punktu widzenia rozważanej problematyki, bardzo istotnej pozycji. Mowa o książce: Zarys metodyki pracy kuratora sądowego. Już w swoim pierwszym wydaniu pokaźnych rozmiarów, bo licząca 479 stron, urosła do 896 w ostatnim, czwartym wydaniu z 2018 roku. Niestety problematyce bardzo szeroko rozumianego zarządzania przypadkiem poświęcone jest raptem kilkadziesiąt stron, a tradycyjna metoda case workingu w pracy kuratora została prawie całkowicie zmarginalizowana ${ }^{40}$. Można uznać takie podejście do kurateli za „znak czasów”, ale zdecydowanie potrzebna jest tu refleksja nad stanem aktualnej metodyki pracy resocjalizacyjnej. Wypada postawić

37 M. Heine, V. Będkowska-Heine, Kompetencje do pracy w zawodzie kuratora sadowego $i$ ich nabywanie w procesie ksztatcenia akademickiego, w: Powinności i kompetencje w wychowaniu osób niedostosowanych spotecznie, red. A. Węgliński, A. Lewicka, Z. Bartkowicz, Lublin 2010, s. 25-37.

38 A. Sajdak (oprac.), Podziat strategii ksztatcenia oparty na pracach B. Joyce, E. Calhoun, D. Hopkinsa oraz D. Gotębniak, materiały do dyspozycji autora.

39 M. Heine, V. Będkowska-Heine V., Kompetencje do pracy w zawodzie kuratora sądowego i ich nabywanie w procesie ksztatcenia akademickiego, dz. cyt., s. 33.

40 Zarys metodyki pracy kuratora sqdowego, red. K. Stasiak, Warszawa 2018. 
pytanie otwarte: w jakim rozumieniu praca kuratora pozostanie wychowaniem resocjalizującym?

Tymczasem coraz więcej badań wskazuje, że jakość oraz spójność relacji pomiędzy przestępcami a ich kuratorami są kluczowe dla skutecznej praktyki - zarówno z perspektywy przestępcy (promowanie motywacji), jak i społeczeństwa czy systemu (udana readaptacja społeczna $)^{41}$.

Relacja ta kształtuje się procesie, wymaga więc czasu na samą diagnozę podopiecznego, a potem na konsekwentne realizowanie planu - programu indywidualnych oddziaływań resocjalizacyjnych. W jaki sposób można wiec zoptymalizować pracę kuratora? Według Roberta Opory,

[...] warto spojrzeć na ideę pracy $\mathrm{z}$ indywidualnym przypadkiem nieco inaczej i podkreślić znaczenie indywidualnych oddziaływań, w których centralną rolę odgrywa relacja między wychowawcą a podopiecznym. Literatura omawiająca tworzenie efektywnej relacji w pracy $z$ indywidualnym przypadkiem podkreśla znaczenie empatii, szacunku, pozytywnego zainteresowania osobą, umiejętnego podejścia do osiągania celów, szczerości, bycia konkretnym oraz przewidywalnym ${ }^{42}$.

„Bycie w relacji” wymaga przede wszystkim czasu na jej budowanie i utrzymywanie, czemu nie sprzyja nadmierne, od lat dyskutowane na łamach literatury przedmiotu, obciążenie pracą kuratorów sądowych.

Jeżeli jednak ustawodawca zakłada znaczące zwiększenie orzekania wolnościowych instrumentów reakcji prawnokarnej na popełniony czyn zabroniony i wymaga efektywnego wykonywania zadań probacyjnych i działalności wychowawczej oraz nieustannego monitorowania procesu resocjalizacji skazanego, to sprawne, a tym samym i efektywne realizowanie celów dozoru elektronicznego wymaga obdarzenia kuratorów jeszcze większym zaufaniem normatywnym i poszerzenia zakresu kom-

${ }^{41}$ S. Rex, Desistance from Offending: Experiences of Probation, „The Howard Journal of Criminal Justice" 1999 , t. 38, nr 4, s. 366-383; B. Beaumont, B. Caddick, H. Hare-Duke, Meeting Offenders' Needs: A Summary Report on the Meeting Assessed Needs Evaluation, Report for the National Probation Service, Home Office, Nottingham 2001; C. Dowden, D.A. Andrews, The Importance of Staff Practice in Delivering Effective Correctional Treatment: A Meta-Analytic Review of Core Correctional Practice, „International Journal of Offender Therapy and Comparative Criminology"2004, t. 48, nr 2, s. 203-214.

42 R. Opora, Sposoby pomiaru efektywności resocjalizacyjnej, w: Profilaktyka i probacja w środowisku lokalnym, red. B. Urban, M. Konopczyński, Kraków 2013, s. 75 . 
petencji decyzyjnej w toku wykonywania kar, z jednoczesnym ograniczeniem do minimum ingerencji sądów i sędziów (referendarzy sądowych) $\mathrm{w}$ to postępowanie ${ }^{43}$.

Tym samym postulowane jest mocno „odciążenie kuratorów od zadań i czynności o charakterze prawnym, administracyjnym czy organizacyjnym na rzecz wyeksponowania i skoncentrowania (pozostawienia) ich aktywności na zadaniach o charakterze probacyjnym, wychowawczym i resocjalizacyjnym. Tak jak zakreśla to ustawa z 27 lipca 2001 r. o kuratorach sądowych ${ }^{44}$, określając w art. 1 charakter zadań sądowych kuratorów zawodowych jako wychowawczo-resocjalizacyjny, diagnostyczny, profilaktyczny i kontrolny" ${ }^{35}$.

W literaturze z obszaru pedagogiki resocjalizacyjnej, w kontekście praktyki sprawowania dozoru nad skazanym/podopiecznym, role i zadania osób odpowiedzialnych za proces resocjalizacji definiowane są przez trzy modele: 1) doradcy - według którego kurator potrafi motywować probanta, 2) edukatora/pedagoga - w tym modelu kurator pomaga gromadzić, rozwijać i wdrażać kapitał ludzki oraz 3) adwokata (sojusznika) potrafiącego rozwijać, a nade wszystko korzystać z kapitału społecznego ${ }^{46}$ (należy dodać: legalnego, pozytywnego kapitału społecznego ${ }^{47}$ ), który w przypadku przestępców jest niejednokrotnie zniszczony. Jeśli zaś nie mogą sami pełnić tych wszystkich funkcji, muszą potrafić pomóc byłemu/przestępcy uzyskać do nich dostęp.

Niestety dzisiaj kuratorzy w swoich działaniach coraz bardziej oddalają się od pełnienia wskazanych powyżej ról. Ich działania koncentrują się głównie na elementach kontrolnych. Roli, jaką pełnią, jest zatem dużo bliżej do strażnika niż do którejkolwiek z wyżej wymienionych.

43 R. Pelewicz, Czynniki normatywne utrudniajace efektywne stosowanie instrumentów reakcji karnej w systemie dozoru elektronicznego na tle ostatnich nowelizacji, dz. cyt., s. 136.

44 Ustawa z dnia 27 lipca 2001 r. o kuratorach sądowych, Dz.U. 2001 nr 98 poz. 1071 ze zmianami.

45 R. Pelewicz, Czynniki normatywne utrudniajace efektywne stosowanie instrumentów reakcji karnej w systemie dozoru elektronicznego na tle ostatnich nowelizacji, dz. cyt., s. 136.

46 S. Farral, F. McNeill, Desistance Research and Criminal Justice Social Work, w: Transnational Criminology Manual, t. 3, red. M. Herzog-Evans, Oisterwijk 2010, s. 214.

47 A. Barczykowska, Kapitat spoteczny a zjawiska patologii spotecznej w wielkim mieście, Kraków 2011. 


\section{Zarys koncepcii metodologicznej projektu badawczego}

Główny problem badawczy planowanego projektu brzmi: Jakie są współczesne modele pracy kuratora sądowego w kontekście podejmowanych nowych zadań w wymiarze sprawiedliwości?

Nie jest zamierzeniem naszego projektu dowodzenie, że dozór kuratorski musi być zawsze organizowany w standardowy sposób oparty na tradycyjnym case workingu lub orzekanie, że jest skuteczny tylko wtedy, jeśli jest prowadzony przez pracownika, z którym sprawca ma bliskie relacje. Raczej chcielibyśmy podkreślić znaczenie pewnego ryzyka związanego z modelem kierowania przestępcą, który staje się coraz bardziej dominujący i określany może być jako przełożenie akcentu z pracy w relacji w ramach case workingu na pracę polegająca na zarządzaniu indywidulanym przypadkiem. Uważamy, że aktualne tendencje w metodyce pracy kuratora oscylują niejako wokół paradygmatu: od case workingu do case managementu, ale jednocześnie widzimy potrzebę diagnozy tego, jak dziś współcześnie kształtuje się dominujący model jego pracy z podopiecznym. Zatem celem poznawczym planowanego projektu jest identyfikacja modeli pracy kuratora z podopiecznymi w kontekście wykonywanych zadań w wymiarze sprawiedliwości. Wśród licznych celów szczegółowych, które określiliśmy, pojawiają się cele związane z diagnozą warunków podejmowania działań, tak leżących po stronie samego kuratora i stosowanych metod pracy, jak i warunków określanych jako systemowe czy zewnętrzne.

Mając na uwadze współczesne tendencje w metodologii badań pedagogicznych w obszarze resocjalizacji oraz szeroko zakrojony cel badań, proponujemy umiejscowić nasze badania w paradygmacie interpretatywnym i wykorzystać strategie jakościowe. Jednakże widzimy również konieczność włączenia do badań na ich wstępnym etapie także tych metod, które pozwoliłyby określić skalę interesującego nas zjawiska na terenie naszego kraju, co pomoże nam się odnieść do opisanych wyżej tendencji w zapobieganiu przestępczości w krajach o wyższej kulturze prawnej. Stąd też refleksja nad hybrydowym ${ }^{48}$ modelem badań, w którym dominujące byłoby podejście interpretatywne,

48 K. Rubacha, Metodologiczne parametry pedagogiki resocjalizacyjnej, w: Uwarunkowania $i$ wieloptaszczyznowośc badań nad resocjalizacja. Podstawy teoretyczne i metodologiczne, red. M. Kowalczyk, M. Fopka-Kowalczyk, K. Rubacha, Torun 2017, s. 129-132. 
a jedynie na etapie wstępnym można by sięgać do badań opartych na podejściu ilościowym. Nie jest zamierzeniem tego artykułu dowodzenie, że dozór kuratorski musi być zawsze organizowany w standardowy sposób lub, że tylko wtedy jest skuteczny, jeśli jest prowadzony przez pracownika, z którym sprawca ma bliskie relacje. Raczej naszym celem było podkreślenie pewnego ryzyka związanego z modelem kierowania przestępcą, który staje się coraz bardziej dominujący.

Uważamy, że najbardziej adekwatnymi do postawionego celu badań metodami badawczymi będzie zastosowanie analizy dokumentów oraz wywiadów eksperckich, wywiadów indywidualnych, a także zogniskowanych wywiadów grupowych, co pozwoli zapewnić jakość planowanych badań poprzez różnego rodzaju triangulacje. Analiza normatywna poprzedzać będzie pogłębione badania wybranych grup kuratorów sądowych, którzy stanowić będą właśnie próbę badawczą. $\mathrm{Na}$ tym etapie projektowania badań nie jest uprawnione ani nawet możliwe bardziej szczegółowe opisanie (postawienie) problemów szczegółowych, celów badań i metod badawczych, gdyż etapy te wymagają szerzej zakrojonych studiów literatury przedmiotu. Ulokowanie badań w pedagogice resocjalizacyjnej, która jest nauką interdyscyplinarną, wymaga wiedzy i umiejętności pedagogicznych, ale i znajomości szerokiego kontekstu kryminologicznego, politycznego, prawnego i społecznego, w którym funkcjonuje kurator sądowy.

\section{Bibliografia}

Alternatywy pozbawienia wolności w polskiej polityce karnej, red. J. Jakubowska-Hara, J. Skupiński, Wydawnictwo Naukowe Scholar, Warszawa 2009.

Austin J., Krisberg B., NCCD Research Review: Wider, Stronger, and Different Nets: the Dialectics of Criminal Justice Reform, ,Journal of Research in Crime and Delinquency" 1981, t. 18, nr 1, s. 165-196.

Bałandynowicz A., Probacja: wychowanie do wolności, Zakład Poligraficzny „Primum”, Grodzisk Mazowiecki 1996.

Barczykowska A., Dzierzyńska-Breś S., Muskała M., Systemy oddziatywań resocjalizacyjnych Anglii i Stanów Zjednoczonych, Wydawnictwo Naukowe UAM, Poznań 2015.

Barczykowska A., Kapitat spoteczny a zjawiska patologii spotecznej w wielkim mieście, Oficyna Wydawnicza „Impuls”, Kraków 2011.

Beaumont B., Caddick B., Hare-Duke H., Meeting Offenders' Needs: A Summary Report on the Meeting Assessed Needs Evaluation, Report for the National Probation Service, Home Office, Nottingham 2001. 
Błachut J., Gaberle A., Krajewski K., Kryminologia, Wydawnictwo Arche, Gdańsk 1999.

Dane Biura Dozoru Elektronicznego Służby Więziennej, <http://www. sw.gov.pl/jednostka/biuro-dozoru-elektronicznego>.

Dowden C., Andrews D.A., The Importance of Staff Practice in Delivering Effective Correctional Treatment: A Meta-Analytic Review of Core Correctional Practice, „International Journal of Offender Therapy and Comparative Criminology" 2004, t. 48, nr 2, s. 203-214.

Farral S., McNeill F., Desistance Research and Criminal Justice Social Work, w: Transnational Criminology Manual, t. 3, red. M. Herzog-Evans, Oisterwijk 2010, s. 203-220.

Heine M., Będkowska-Heine V., Kompetencje do pracy w zawodzie kuratora sqdowego i ich nabywanie w procesie ksztatcenia akademickiego, w: Powinnosici i kompetencje w wychowaniu osób niedostosowanych spotecznie, red. A. Węgliński, A. Lewicka, Z. Bartkowicz, Wydawnictwo UMCS, Lublin 2010, s. 25-37.

Jaroch W., Polityka karna - strategia punitywna czy liberalna, „Studia Prawnoustrojowe" 2012, nr 15, s. 49-61.

Krajewski K., Czy w Europie istnieją dwie odrębne strefy „klimatu penalnego”?, w: Państwo prawa i prawo karne. Ksiega jubileuszowa Profesora Andrzeja Zolla, t. 2, red. W. Wróbel, P. Kardas, T. Sroka, Wolters Kluwer, Warszawa 2012, s. 1413-1430.

Kusztal J., Prawne podstawy kurateli sądowej, w: Wspótczesna kuratela sądowa, red. B. Zinkiewicz, GWSP im. A. Hlonda w Mysłowicach, Mysłowice 2006, s. 11-20.

Kusztal J., Siuda A., Probacja w sprawach nieletnich - doświadczenia szkockie, w: Profilaktyka i probacja w środowisku lokalnym, red. B. Urban, M. Konopczyński, Wydawnictwo UJ, Kraków 2013, s. 429-436.

Maty Rocznik Statystyczny Polski. 2016, GUS, Warszawa 2016.

Melezini M., Punitywnośc wymiaru sprawiedliwości karnej Polsce w XX wieku, Temida 2, Białystok 2003.

Ministerstwo Sprawiedliwości, Sprawozdanie MS-S40 na dzień 30.06.2014 r., <https://isws.ms.gov.pl/Data/Files/_public/isws/jednoroczne/2014/spr_ zbior_2014/ms-s40-r-2014.pdf>.

Moczydłowski P., Przesteppa na uwięzi. Elektroniczny monitoring sprawców przestepstw, (Zeszyty Naukowe „Ius et Lex”, z. 2), Fundacja „Ius et Lex”, Warszawa 2006.

Muskała M., „Odstapienie od przestępczości” w teorii i praktyce resocjalizacyjnej, Wydawnictwo UAM, Poznań 2016.

Niewiadomska-Krawczyk M., Kurator sqdowy jako funkcjonariusz publiczny-rozważania na tle art. 115 par. 13 pkt 3 kk, „Przegląd Więziennictwa Polskiego" 2016, nr 93, s. 13-26.

Opora R., Sposoby pomiaru efektywności resocjalizacyjnej, w: Profilaktyka i probacja w środowisku lokalnym, red. B. Urban, M. Konopczyński, Wydawnictwo UJ, Kraków 2013, s. 69-76. 
Pelewicz R., Czynniki normatywne utrudniajace efektywne stosowanie instrumentów reakcji karnej w systemie dozoru elektronicznego na tle ostatnich nowelizacji, „Przegląd Więziennictwa Polskiego” 2017, nr 95, s. 125-144.

Poklewski-Koziełł K., rec.: David Garland, The Culture of Control: Crime and Social Order in Contemporary Society, Chicago 2001, „Państwo i Prawo” 2002, nr 12, s. 85.

Pospiszyl I., Patologie spoteczne, Wydawnictwo Naukowe PWN, Warszawa 2008.

Rex S., Desistance from Offending: Experiences of Probation, „The Howard Journal of Criminal Justice" 1999, t. 38, nr 4, s. 366-383.

Rubacha K., Metodologiczne parametry pedagogiki resocjalizacyjnej, w: Uwarunkowania $i$ wieloptaszczyznowośc badan nad resocjalizacja. Podstawy teoretyczne i metodologiczne, red. M. Kowalczyk, M. Fopka-Kowalczyk, K. Rubacha, Toruń 2017, s. 129-132.

Sajdak A. (oprac.), Podziat strategii ksztatcenia oparty na pracach B. Joyce, E. Calhoun, D. Hopkinsa oraz D. Gotębniak, materiały do dyspozycji autora.

Siemaszko A., Gruszczyńska B., Marczewski M., Atlas przestępczości w Polsce. 3, Oficyna Naukowa - Instytut Wymiaru Sprawiedliwości, Warszawa 2003.

Stańdo-Kawecka B, Ruch What works $i$ „nowa resocjalizacja” - nowa perspektywa w polityce karnej?, w: Węztowe problemy prawa karnego, kryminologii i polityki kryminalnej, red. V. Konarska-Wrzosek, J. Lachowski, J. Wójcikiewicz, Wolters Kluwer, Warszawa 2010, s. 891-907.

Sztumski J., Czy możemy mówić o patologii spotecznej, w: Zjawiska patologii spotecznej. Uwarunkowania, rozmiary, profilaktyka, prognozy, red. T. Soltysiak, Wydawnictwo Uczelniane WSP, Bydgoszcz 1995, s. 11-18.

Urban B., Teoria resocjalizacji w strukturze nauk spotecznych, w: Resocjalizacja, red. B. Urban, J.M. Stanik, Wydawnictwo Naukowe PWN, Warszawa 2007, s. 17-30.

Węgliński A., Autoprezentacja bezpośrednich oddziatywań wychowawczych społecznych kuratorów sqadowych „Lubelski Rocznik Pedagogiczny” 2016, t. 35 , z. 2 , s. $55-83$.

Wójcik D., Probacja - rozwiązania prawne w niektórych krajach europejskich, „Archiwum Kryminologii” 1999-2000, t. 25, s. 29-79.

Zarys metodyki pracy kuratora sadowego, red. K. Stasiak, Wolters Kulwer, Warszawa 2018.

\section{A k ty praw ne:}

Ustawa z dnia 25 lutego 1964 r. - Kodeks rodzinny i opiekuńczy, Dz.U. 1964 nr 9 poz. 59, ze zmianami.

Ustawa z dnia 26 października 1982 r. o postępowaniu w sprawach nieletnich, Dz.U. 1982 nr 35 poz. 228 ze zmianami.

Ustawa z dnia 26 października 1982 r. o wychowaniu w trzeźwości i przeciwdziałaniu alkoholizmowi, Dz.U. 1982 nr 35 poz. 230 ze zmianami, tj. Dz.U. 2016 r. poz. 487. 
Ustawa z dnia 6 czerwca 1997 r. - Kodeks karny wykonawczy, Dz.U. 1997 nr 90 poz. 557 ze zmianami.

Ustawa z dnia 6 czerwca 1997 r. - Kodeks karny, Dz.U. 1997 nr 88 poz. 553 ze zmianami.

Ustawa z dnia 27 lipca 2001 r. o kuratorach sądowych, Dz.U. 2001 nr 98 poz. 1071 ze zmianami.

Ustawa z dnia 27 lipca 2001 r. Prawo o ustroju sądów powszechnych, Dz.U. 2001 nr 98 poz. 1070 ze zmianami.

Ustawa z dnia 7 września 2007 r. o wykonywaniu kary pozbawienia wolności poza zakładem karnym w systemie dozoru elektronicznego, Dz.U. 2007 nr 191 poz. 1366, uchylona Ustawą z dnia 20 lutego 2015 r. o zmianie ustawy - Kodeks karny oraz niektórych innych ustaw Dz.U. 2015 poz. 396.

Ustawa z dnia 20 lutego 2015 r. o zmianie ustawy - Kodeks karny oraz niektórych innych ustaw Dz.U. 2015 poz. 396.

\section{ADRES DO KORESPONDENCJI:}

Dr hab. Maciej Muskała

Uniwersytet im. Adama Mickiewicza w Poznaniu

Wydział Studiów Edukacyinych

e-mail: muskala@amu.edu.pl

\section{Dr Justyna Kusztal}

Uniwersytet Jagielloński

Instytut Pedagogiki

e-mail: justyna.kusztal@uj.edu.pl 